\title{
Tribute to \\ Kamau Brathwaite (May 11, 1930 - February 4, 2020)
}

\author{
By Timothy Reiss \\ Emeritus Professor, Comparative Literature, New York University, \\ Visiting Scholar, English, University of Hawai'i-Manoa \\ timothy.reiss@nyu.edu
}

In Toronto, in 2006, after reading Born to Slow Horses, which had just won the International Griffin poetry prize, Kamau Brathwaite answered an interviewer's question:

Poetry sometimes forgets about relationships, eh? Because it tries to deal with too much abstraction. And in the end it's the relationships which are so important - especially in a world like today where there's so much disaster and so much fragmentation, I think the notion of relationship, which you have just suggested, is very, very important... yeh, that's a good point to bear in mind.... and in fact when you listen to our poets it might be a good idea to discern who is aware of the importance of relationships and who is not.

Kamau's poetry, history, literary and cultural criticism, theatre, teaching and thinking are deeply about relationships of all kinds and levels. To be present at one of his spellbinding, extraordinary readings - even just to watch one of the dozens online - was/is to be taken up in a community of rhythm, of melody, of sound and thought that binds his audience in a kind of communion. I well remember Patricia Hilden and myself going down from Cambridge to Canterbury in early 1990 to hear Kamau give the T. S. Eliot lectures at the University there, after our NYU Department had already successfully wooed him to join us the following year. The lectures filled a large auditorium to bursting, with all the luminaries present one might expect. Kamau's performance began, as they often did back then, with his charismatic "Calypso" from Rights of Passage, the first book (1967) of what had long since been published as The Arrivants trilogy (1973):

The stone had skidded arc'd and bloomed into islands:

Cuba and San Domingo

Jamaica and Puerto Rico

Grenada Guadeloupe Bonaire

Curved stone hissed into reef

wave teeth fanged into clay

white splash flashed into spray

Bathsheba Montego Bay

Bloom of the arcing summers ... 
The poem continues with wonders of the plantation for its white owners, destruction and savage demeaning of its slaves, moving into the hopeful, grieving drumming dancing singing of calypso. Kamau paced out the song of his stone cast and sliding across the Caribbean's waters, beating his rhythm with a pianist's fingers on the podium, starting quietly with the motion of the stone and modulating his melody, pitch, tone and volume, moving his listeners, his spectators, to feel the settling of islands in ocean. Valerie Eliot, seated just in front of us and looking at first skeptical, breathed out, gasped even, her thrilled surprise. The audience was already gathered together in the palm of Kamau's metrical hand, and stayed so for the hour of his performance. As he ended, we all sat tied in momentary silence (I'd say "stunned," but for the cliché), before standing as one in ovation. He gave three such lectures.

He was not just a great performer. He is by general assent one of the greatest poets of his time (I would say the greatest). When Derek Walcott won the Nobel Prize in 1992, the New York Times ended its article by saying that of anglophone Caribbean poets, it should probably best have gone to Brathwaite, though its author was also stirring old tilts, which often sought to set two friends, "European" Walcott and "African" Brathwaite, against each other. ("Walk good amigo," Derek, wrote Kamau, in his farewell tribute of March 2017). The Times after all (like the Nobel) typifies a hegemonic culture ever eager to put Nelson's telescope to its blind eye to not see non-Euro-American cultures: a fight from which Kamau never shied. Unlike some of his peers, he did not envy other artists (regularly teaching in his classes alleged "rivals" like George Lamming, V. S. Naipaul and Walcott-whose Dream on Monkey Mountain he had his NYU students perform for us and others-an embrace I have known other teacher-artists refuse). He was notably generous in helping younger artists, as he was to his students, undergraduate and graduate, with whom he might sit endless hours mulling their papers, theses and dissertations. He could be demanding, having students who he thought could do better than his initial grade indicated, rewrite until they reached a grade nearer their abilities. For he listened, and listened, and listened to his and others' students. He once flew with me to Emory University (for just his airfare, because the group inviting him was unable to afford more), to give a talk and listen just so to students; taking deep pleasure too in the MLK Center and its visiting schoolchildren, in Sweet Auburn, in just being there. The students whom he met, talked to, and shared a seminar with remember him still with awe and affection, even after so short a visit. The devotion of his NYU students is of a piece. Relationships.

Kamau joined our Department of Comparative Literature in Fall 1991. He stayed for 20+ years, retiring Emeritus in 2013. He came after 30 or so years at UWI's Mona campus, whose end years had been a "time of salt." With the abrupt cancer death of his wife Doris ("Mexican") in 1986, ruin of his Jamaican mountain home and its vast 50-year+ archive of Caribbean poetry, art, music and culture in 1988 by Gilbert, the most destructive hurricane ever to hit the island, and a 1990 attack on his life in his Kingston apartment. Out of his grief, he later wrote of all these: The Zea Mexican Diary (1993), Shar = Hurricane Poem (1990), Trench Town Rock (1994). All strove to figure the meaningful trammelings their events emerged from, made and remade in life.

Lawson Edward Brathwaite was born in Bridgetown, Barbados, on 11 May 1930. He grew up with his sisters Mary, Thelma and Joan (their brother Frederick died an infant) in the "Round House" on Bay Street, near the town center, its "back" giving onto Browne's Beach. The house, even then over a century old, was officially "listed" for its architectural and historic

Cultural and Pedagogical Inquiry, Summer 2020, 12(1), pp. 343-352

ISSN 1916-3460 @ 2020 University of Alberta

http://ejournals.library.ualberta.ca/index.php/cpi/index 
interest in 1984, and similarly certified by the Barbados National Trust on Kamau's $80^{\text {th }}$ birthday in 2010. The beach and the sea, the house's long history are ingrained in his poetry and historical thought: "By these shores I was born: sound of the sea / came in at my window, life heaved \& / breathed in me then / with the strength of that turbulent soil" (Barabajan Poems [1994] 83)—its joys and pleasures, "the movement, the tides, the changeable nature of the sea, its generosity and even its cruelty," his sisters wrote in the November 2010 of Bim, honoring Kamau's same birthday. They recall a terrifying moment of its cruelty when in the sea with their mother, all of them still small, one a baby, the abrupt-receding water made them look up to see a tidal wave racing in, to toss them hither and yon against the sand. Kamau set the memory in "Return of the Sun," written in 1951, published in Sun Poem (1982:77), the second part of his Ancestors trilogy (2001). He recalls, too, like his sisters, wartime fear of attack from the air as from the sea behind their home (though they were not far from it when they removed to their father's hometown of Mile \& Quarter, 13 miles north of Bridgetown, and its name's distance from the sea), and the torpedoing of the Canadian freighter Cornwallis in Carlisle Bay off Browne's Beach (Barabajan 112ff., 347-61).

At secondary school, first at Combermere (where Lamming also was), then at Harrison College from 1944, besides being athletic enough to be one of the first Barbadians to race a bicycle round the island (as the winner), Kamau managed to develop a weekly jazz show on local radio, finally finding himself in controversy toxic enough to force the program off, some listeners condemning its music as lasciviously immoral (Barabajan 31-9). The lifelong grounding of Kamau's poetry in jazz, blues, calypso, reggae marks his roots in and fidelity to his diaspora culture and stern stubborn reply to those who demean and deny it. Cultural conservatism would bedevil Kamau's ties to his native land, as he sought to sustain, forge, a "nation language" and culture. From them he lifts a voice to confront and sap the heroic lore of Nelson's telescope and reject its justifying claims, while generously hoping to repel its vices and abuses yet include its virtues in a mestizaje of Indio-American, European and African strands. "Bajan culture...is this shared collective xperience on a rock of coral limestone, half-way from Europe, half-way (?back) to Africa; but like Nelson's statue in both Trafalgar Squares - but I'm talking about ours [Bridgetown's] - seeing, it see/ms, with only one \& outer eye of the plantation; while the other inner eye \& world of art \& dream\&meaning was for too long a time ignored, eroded, submerged; treated not only as if it did not xist, but that it could not: Carry on Big Inglan, Lil Inglan is behine yuh!” (Barabajan 21-2).

Kamau's poetry defies that internalizing of oppression, to face its history and its causes, causers; to forge a home culture from forcibly fragmented language and naturally fragmented geography, where the wages of Western economies have been and still are further splinterings. For that the force of the first unceasingly ruins. The second is evident not just in the torpedoing of ships, but in the dynamiting of his beloved Pelican Island and inter(n)ment of its shard in the mainland (as the artsy tourist retail place of "Pelican Village!") to make the deepwater port that lets colossal cruise ships dock; in the nearby reshaping of the shore to fit a Hilton resort; the building of another vast garish hotel over older small houses and apartments in St. Lawrence Gap; or the threatened road over his Cow Pastor home. Kamau has continuously battled this desolation. At times accused (I use the word advisedly) of narrowing into an "African" prism a Caribbean culture whose urge has been always towards Europe-England in Kamau's case ("Afro-Saxon," he said), Kamau's work, hopes and goals are, as any careful reader knows, far wider and more generous.

Cultural and Pedagogical Inquiry, Summer 2020, 12(1), pp. 343-352

ISSN 1916-3460 @ 2020 University of Alberta

http://ejournals.library.ualberta.ca/index.php/cpi/index 
In 1949, Kamau won a Barbados Scholarship to Pembroke College, Cambridge, in 1950, to study English and History. That year, his old Combermere "godfather," Frank Collymore (Barabajan 28, 39-42), the now-legendary editor of Bim, included his first published poem, "Shadow Suite," in that journal. Meantime, Kamau faced the "medieval garden" of Cambridge, the strangeness of its climate with its first-ever-seen snow, and the reality of racism. Still, he acknowledged that its perception was at times his own, as when he attempted the Cambridge University Players Theatre to be told by the future great director Peter Hall that he must start by sweeping the stage. "I mean this was something that even my Mother couldn't get me to do \& it brought back all that slave/menial/mentality bit." Later he realized that he was simply being told he'd have to start "at the beginning/rather than the big inning...." For "it was these same Cambridge types who accepted my up to then most important 'Caribbean' poem, 'Calypso', for inclusion in Poetry from Cambridge (1951) and praised my 'Snow' poems" (Barabajan 57-8; for the poem, Other Exiles 1975:7). Years later he and I went through a similar experience when I, as Department Chair, had to insist he submit a grade whose months of delay, while he sought those rewrites desired from a much-respected student, were not just preventing release of Fellowship funds but threatening the very Fellowship: "ok massa; yes 'deed massa." The later honor of his dedication of both a poem and a book signaled the same adjustment/forgiveness/ understanding.

After his BA and another year for an Education Diploma, Kamau went to the Gold Coast in 1955 as Government Education Officer, first assigned to coastal Takoradi, 140 miles west of Accra, where he was for Ghana's independence in March 1957. Later he would go to the forested area of trans-Volta Jasikan on the Togo border, 200 miles north of Accra. This would be central to the creation of his yet-unpublished third trilogy. Back in Barbados in 1960 on leave, Kamau met and in three weeks married Doris Wellcome from Guyana, his first beloved muse. Mexican, or Mex, as he called her, accompanied him back to Ghana. Over the next two years, they built a children's theatre, from which four of Kamau's plays were printed together in 1964. Odale's Choice came out in 1967. Often staged, it is now a schools' staple at the annual Jamaica Drama Festival. In Ghana, too, they had their son Michael Kwesi (Kamau's granddaughter Ayisha came along in 1990).

In 1962 Kamau had become Resident Tutor at the UWI's Extra Mural Department in St. Lucia, moving in 1963 to the History Department at the UWI's flagship Mona campus. Two years on, he returned to England to do a history doctorate at the University of Sussex (1965-68). These became dramatic years. In 1966, Kamau, John La Rose and Andrew Salkey co-founded the Caribbean Artists Movement (CAM) in London, he its secretary-treasurer. This, his sisters noted in 2010, "is still nurturing young persons from throughout the diaspora." Rights of Passage (1967), Masks (1968) and Islands (1969) were published, and put together as The Arrivants in 1973. They won him Britain's 1970 Cholmondeley Award for poetry. He also wrote/edited his 3-volume Caribbean history, The People Who Came (1968-72), for use in the region's schools. His 1968 doctoral thesis, The Development of Creole Society in Jamaica, 1770-1820 (OUP), came out in 1971 (2nd ed. 2005). In 1968, he returned to Mona, where he worked on expanding CAM to the islands, most visibly realized by his launching the journal and publishing house Savacou in 1971.

This last year saw another dramatic bound. He was now known as a major poet, fertilely original historian, thoughtful cultural and literary critic, forger of new diasporic relations and realities, and educator in three continents. He was an exemplary voice to capture the focal aim 
and nature of the educational, cultural and political upheaval being undertaken at Nairobi University, where Ngũgĩ wa Thiong'o and his colleagues were reworking the English Department into a new Department of Literature, guided by his/their manifesto, since hailed as the founding charter of postcolonial studies. Ngũgĩ knew Brathwaite from CAM's first days and invited him in 1971 on a City of Nairobi Scholarship as a first diaspora visitor, a resounding signal that England's literary centrality was being displaced. One day, this visitor was taken to a gathering at Ngũgĩ's village of Limuru, to find himself in a ceremony where Ngũgĩ's mother welcomed home the "prodigal" while the large family, villagers, writers and teachers who "had motored up from Nairobi" joined in "chanting deep down inside their chests \& deeper down into their very bellies searching for my nam so they could find my name." Edward emerged from the chant as Kamau, baptized by Ngũgĩ's mother spitting on his chest as he knelt with his shirt "ripped open" (Barabajan 236). Ngũgĩ just now (Personal Communication) recalls how dancing, singing women welcomed him as 'their son come back home, where his umbilical cord, was buried.' My mother gave him the name. So I feel like my brother...has passed on. But his living spirit is in all the works he has left us and the world.

It could be said that much of Kamau's work since this germinal event has been to explore the depth of nam, of personal, spiritual, social, cultural, political identity, in the Ancestors sequence no less than in Barabajan Poems or ConVERSations with Nathaniel Mackey (1999), or indeed in those works written in his "time of salt," as nam was rocked and undermined to its very core.

Back in Jamaica, besides being also assistant/associate editor of Bim from 1965-78 (Barabajan 333), Kamau expanded Savacou as a major outlet for new Caribbean writing. It had, of course, to be funded, and to help with this students and friends (many of whom are themselves now major writers, editors, critics and who knows what else), deployed across the island. Pamela Mordecai tells a hilarious tale of presenting him a well-funded offer for a half-page brassiere ad. He was not amused. The prudery casts an odd shadow on the importance of women throughout his work, to say nothing of his practical support for women poets and performers. (Pam's story is a whole lot funnier, as is her wont, but here my prudery seems the better part of valor.)

Along with Savacou's development and Kamau's teaching, most of the 1970s-80s at Mona were years of joy and fruitful performance-perhaps their best description. Rights of Passage had four theatre stagings between 1967-71, and Kamau shared in dramatic work from Marina Maxwell's “people's” Yard Theatre, to Rex Nettleford's National Dance Theatre Company of Jamaica and the influential working-women's Sistren Theatre Collective from its 1977 founding. Sistren's first artistic director, Honor Ford-Smith, recalls Kamau's constant encouraging counsel and the inspiration his work gave Jean Small in directing/scripting the 1980 ensemble piece Nana Yah (on whose central personage, the seventeenth-century revolutionary Nanny, Kamau wrote his 1977 Wars of Respect). These years saw publication of Mother Poem (1977), Sun Poem (1982) and X/Self (1987), that in 2001 he would re-vision under the aegis and, he said, guiding breath of Sycorax into Ancestors. Like others of his poems these have been staged. Ford-Smith remembers directing a very successful UWI student Motherpoem, with whose cast Kamau would regularly discuss "what he was doing in the words." Such performances continue, and Christine Pagnoulle of the Université de Liège mentions stagings at Paris/Villeneuve-sur-Lot of Et ce n'était pas qu'on allait quelque part, based on RêvHaïti, her translation of DreamHaiti (1995). 
Among books of poetry outside the trilogy from these years are Days and Nights, Other Exiles (both 1975), Black + Blues (1976), winner of the first of his four Casa de las Américas prizes, Soweto, Word Making Man (both 1979), Afternoon of the Status Crow (1982), Third World Poems (1983), Jah Music (1986) and on.... From 1975 to 1979, Kamau was cultural advisor to the Barbados government (as he would be again from 1990). From 1979 too, and for the next 30 years, he was on the board of directors of UNESCO's History of Mankind project. In 1983, a year when he won a Guggenheim and a first of two Fulbright awards, UWI rewarded his historical and critical work with a professorship in Social and Cultural History. The Queen's 1987 $21^{\text {st }}$ Anniversary of Independence Honours List, named him Companion of Honour-Barbados.

As Kamau became ever more renowned as poet and performer, and already known as a ground-breaking historian, he was writing many essays of vital literary and cultural criticism. Some of these would be collected as Roots, 1986 winner of the Casa de las Américas prize for criticism. In 1974 came Contradictory Omens: Cultural Diversity and Integration in the Caribbean (1974), on cultural conflicts, contradictions and necessary transculturations that perforce characterize the Caribbean's places and cultures, a meditation barely more than a booklet that had disproportional influence on its readers. It did so surely not least because it embodied in its restrained carefulness that "miracle of tact and selfless grace" (61), that its author argued as essential to negotiate these multiple contradictions, a grace often manifest in his own conduct and activities. A decade on he repeated the effect in replying to a small segment of his meditation in History of the Voice: The Development of Nation Language in Anglophone Caribbean Poetry (1984), arguing that local languages entail a metrics and rhythm entirely distinct from English tradition. He famously urged that the dominant pentameter of English poetry from Chaucer falsifies Caribbean experience, cultural, historical, physical. "It carries with it a certain kind of experience, which is not the experience of a hurricane. A hurricane does not roar in pentameters. And that's the problem: how do you get a rhythm which approximates the natural experience, the environmental experience?" (History 10). The needed rhythm is rooted and trammeled in the skipping stones and rock-hidden water, both bearing spirit of place. With experience of place tied in form goes a bond of culture.

That bond was about to be shattered by Doris' death in 1986 and Gilbert's roar in 1988, whose shrieking power, destroying his house and archive, Kamau would capture, with Sycorax's help, in Shar. Honor Ford-Smith encountered him for many months of the immediate aftermath:

We crossed paths at Harvard. I was there for a fellowship and I think he was teaching. It was the year of Gilbert and he was in deep mourning. I remember listening to him speaking about losing Doris and then the house and feeling so overwhelmed by the depth of his sadness.

But then from time to time he would reach out... a combination of unexpected and generous interest in my work and an expression of his own vulnerabilities. This was the thing. This combination of vulnerability and the calm metal of his voice.

(Personal Communication)

Typically, too, and not only in the direct writings, he sought to understand why there, why then, why him. It was about now that he began to seek the relationships that made him tie 
the Saharan sirocco to Atlantic hurricanes - and, given the murderous events at his Kingston apartment in early 1990 and the pistol attack on him, it may be beyond coincidence that the sirocco's effect in southern Italy are downpours called "blood rain" (from the red sand coloring it). These physical relationships, known to be intimately bound with culture and its expressions, as History of the Voice early sought to explain, would ultimately lead Kamau to his concept of tidalectics.

A first startle after his move to New York University took place as he participated in a 1992 panel at a conference on Columbus. Adjusting his chair, Kamau abruptly disappeared offstage behind the back curtain. He was to contemplate this "death" and his thereafter ghostly return in "I Cristóbal Colón," so published several times before its final version, "I Cristóbal Kamau" appeared in 1995. Two editions of Middle Passages appeared in 1992 (UK) and 1993 (USA), a new, slightly Sycoraxed (as it were) Black + Blues in 1995, both of these, with Daniel Javitch's help, at New Directions (like Ancestors and Dreamstories(2)). The Zea Mexican Diary, Trench Town Rock came and, also in 1994, Barabajan Poems, Sycorax prose-poem exploring (his) life and identity. That year he was awarded the Neustadt International Prize for Literature, as if to set a period to a catastrophic time. At long last, the INS let his second great love muse, Beverley Reid ("Dream Chad"), permanently into the US. He had begun writing those personal, political, highly experimental prose-poems that became the two volumes of Dreamstories (1994, 2007), that so often grow grieving/ous glory from disaster. For this stricken stutter, as Kamau once put it, did hiss and splash into a bloom of arcing summers.

Shortly after arriving in NYC, Kamau established Savacou North, really now a publishing house for this astonishing bloom, an endeavor for which he drew on the devoted and efficient help of Ronnie Pardo, his graduate student Isis Costa, and Beverley, who had been a rock through his salt years. They married in 1998, to the song of the eponymous epithalamium from Words Need Love Too (2000:22). The practical work for Savacou North was done in his NYU office, where book boxes grew like Alice, threatening total takeover. Isis recalls clambering from his window to the roof, level with the office floor, trying to make space to work. Later, this large endeavor and his many new volumes, readings and lectures benefitted for more than a decade from Susan Protheroe's artistic, accounting and administrative labors. This piling might symbolize both a deep inhaling before the long exhale of re/life, and that great accumulation of shards and layers that many think explains the colossal outpouring of Caribbean artistic accomplishment.

In that fertile 1994, Kamau began performing the Rwanda Poems, second part of a third trilogy. He was more and more exploring his computer Sycorax "style," as some call it, but that was far deeper: a breathing from the soul or, better, the nam, of ocean tides, of colonized and downthrust peoples, ruined worlds and cultures to be rekindled and made to blaze anew. Pam's bra ad story gets cast in new light. Pat Hilden and I well remember, after Kamau's first Rwanda performance at NYU, walking with him in the dark early December evening to take our friend Miryam Yataco home to her place on Second Avenue so she'd not have to walk alone. As Kamau rejoiced in the city streets, the sights, sounds, even smells of the clear cold night, Pat turned to him: "That's fine for you, a 6'3 man; impossible for us. Why d'you think we're taking Miryam home?" Silence. Then, "I hadn't thought of that. You're right." Of course, he'd thought of it. He'd after all written Caribb[ean] Wo[men] during the Period of Slavery (still unpublished), signal bearers of colonial wo(e). He loved Mex and Chad, who thread his work as more than 
themselves (as Pam Mordecai and Elaine Savory put it). Sycorax draws silencing into speech and life. What he maybe felt he'd not yet got was how women might speak themselves in his writing. Its difficulty groans in that of even seeing Sycorax's double, Namsetoura, who emerged from the slave cemetery beneath Cow Pastor, breaking three camera lenses before Kamau could get a vague photo, one eye blazing, one staring, her face ghostly (on the front cover of Born to Slow Horses, her story 118-21, and The Namsetoura Papers, Hambone 17, 2004). Hard as this is ("literally" impossible for a male writer), he laments that publishers make it harder by trying to reproduce Sycorax, but so that "she can't breathe," preventing her speaking through him.

This is what he tried to do in Dreamstories, as in the amazing 2-volume $M R$, towards which he'd been writing since 1994, of which a fragment appeared in Sisyphus and Eldorado in 1997, the year before the whole thing (more or less) won Kamau's third Casa de las Américas prize, to be published in 2002. This is tidalectics at work, where a banal pop "magical realism" deepens into an intricately layered unpacking of poetry, culture, the oceanic Caribbean, the local in the global, of real place and fraught people as active foundations of cultural, indeed human, being. The best and most expansive reading I know of this is his student Chris Winks' joint review of it with the 2005 Slow Horses (XCP 17 [2007]). Tidalectics, said Kamau in 1999, effects a fused geographic, cultural, climatic and political ecology of oceanic tidal motion always rippled by cross-currents, swells, skipping stones.... The Middle Passage and western "missilic" culture, as Kamau calls it, are distortions in a tidalectic process that will alter a dialectic of "progress" (thesis, antithesis, synthesis) to a softer circuitry, from ocean and island dynamics (ConVERSations 34). It voices ecologies of exchange, circulation and knotted cultural equalities, compassion and knowings. The goal has been adopted in venues from a Duke University dissertation by Carmen Beatriz Llenín-Figueroa (2012, setting key Caribbean writers under Kamau's aegis!) to the exhibit and shipboard academy built by the Thyssen-Bornemisza Art Academy and the book that came from it, Tidalectics: Imagining an Oceanic Worldview through Art and Science, ed. Stefanie Hessler (MIT Press, 2018), concerned mostly with the Pacific. In another register, tidalectics underlies Ngũgĩ's Kamau - titled Something Torn and New (2009) and his Globalectics (2012).

For Kamau himself, MR was followed by Golokwati, a large compilation, mostly from earlier works, of its title's "resting-place" thanks for the several big $70^{\text {th }}$ birthday celebrations, another furthering of relations and love, repeated to his verbal medium in his 2000 Words Need Love Too. The resting was surely needed, for Kamau and Beverley were watching when the planes of 9/11 struck the Twin Towers, and he struggled downtown from his nearby Washington Square apartment to be choked in smoke and blowing ash, an omen of ashen times to come. Out of it first came Ark, surely the most potent poetic memorial to the ruin (2004), with another version in Slow Horses (92-114). As this last was winning Canada's International Griffin Prize in 2006, Jamaica gave him the Musgrave Gold Medal for Literature, and Barbados first prize in its Frank Collymore Literary Endowment competition for Missa Solemnis, first part of his third trilogy.

These pleasures were soon to be offset by what Kamau came to call his "cultural lynching." This involved the mysterious disappearance from at least early 2007 of many writings, glossed texts and artifacts (including the Musgrave medal) from his and Beverley's NYU apartment. By late 2008, they were desperate, and NYU's administration responded as best it could, with high tech locks and monitors. But matters reached a pitch where they felt unsafe in 
both being out at once. Events remain a mystery, not least as some at least of the missing materials apparently turned up. He let me read his much-annotated Missa Solemnis sometime between 2005 and 2007 (or at least skim it, since he'd not let it out of the apartment), telling me later that it was among items stolen. Yet he published appreciable parts of it in Poui, Cave Hill's Journal of Creative Writing, in 2010 (no. 11, December). Events were anyway frighteningly real for Kamau and Beverley, and of a piece with those of which the third trilogy is a record (maybe fourth, since Kamau has referred to the three "time of salt" works as a third trilogy).

Missa Solemnis is the first part of the trilogy. Its origin dates to 1958 or 1959, when he bought Beethoven's Missa Solemnis (Toscanini conducting) in Accra to listen to in his forested northern Ghana: "Its continental/intercontinental vision \& vibration. Its sorrow. travel/ travail of loneliness inside that $<<<$ great ensemble. seem-ing to come out of the vast night-f] forest mindscape I live(d) in in that time" (Poui 13). Tidalectics was already at work at umpteen levels, tying Europe, Africa, the Americas, music and the land, the singular and multitude.... The links could go on: Golokwati, later place of rest, is a village on the road from Jalikan to Accra. The music that "xplained' where I was. Came out of that landscape of the heart as if that landscape had in a sense composed it. and it it. As if he was native of it, you know what I mean - the whole drift of the W Africa whe i was. Out of the Sahara" (Poui 13), that space- and continent-crossing music also crosses many times, its own to Kamau's and, there, from 1958 to 2000 to 2010. It fuses, too, somehow, with those Sahara-created Atlanticcrossing hurricanes. Its sorrow leads into the trilogy's second part, the Rwanda Poems of genocidal massacre and (post)colonial horror, and third, Dead Man Witness, writing his cultural lynching, elements of which furnished three volumes, Strange Fruit (2016), Liviticus (2017) and The Lazarus Poems (2017), winner of the 2013 Collymore competition first prize.

Meantime, the 2009 Danzantes del tiempo, an anthology of Kamau edited by Chris Winks and translated by him and Adriana González Mateos, won him a fourth Casa de las Américas prize in 2011. He won the W. E. B. Dubois Award in 2010, when his non-trilogy collection Elegguas was also published (with another reworked brevity of Ark's terrible lament, 81-6), the Poetry Society of America's Robert Frost Medal in 2015, the PEN/Voelcker award for poetry in 2018, and the Bocas Henry Swanzy Award for Distinguished Service to Caribbean Letters just before his death. He leaves myriad unpublished or partly published poetry, history and criticism. Let's hope most will see the light of day. A great world voice has left us.

We went, four old friends of Kamau, to the Buddhist temple in Oah'u's Valley of the Temples. Kamau would have rejoiced in the calm of its lawns and trees, its squabbling fish, stately black swans and other birds parliamenting and singing, even as he grieved over equally visible tourist destruction, as he did in his own island. For him, for ourselves, for Pam and Martin Mordecai, we lit incense of remembrance and to help scent his way. Outside, we used the pendant log softly to strike the temple gong. As its low groan faded, we swung harder, sending its resonance across the golden blue sky and out over an ocean whose tides and swells are Kamau's body and soul. 


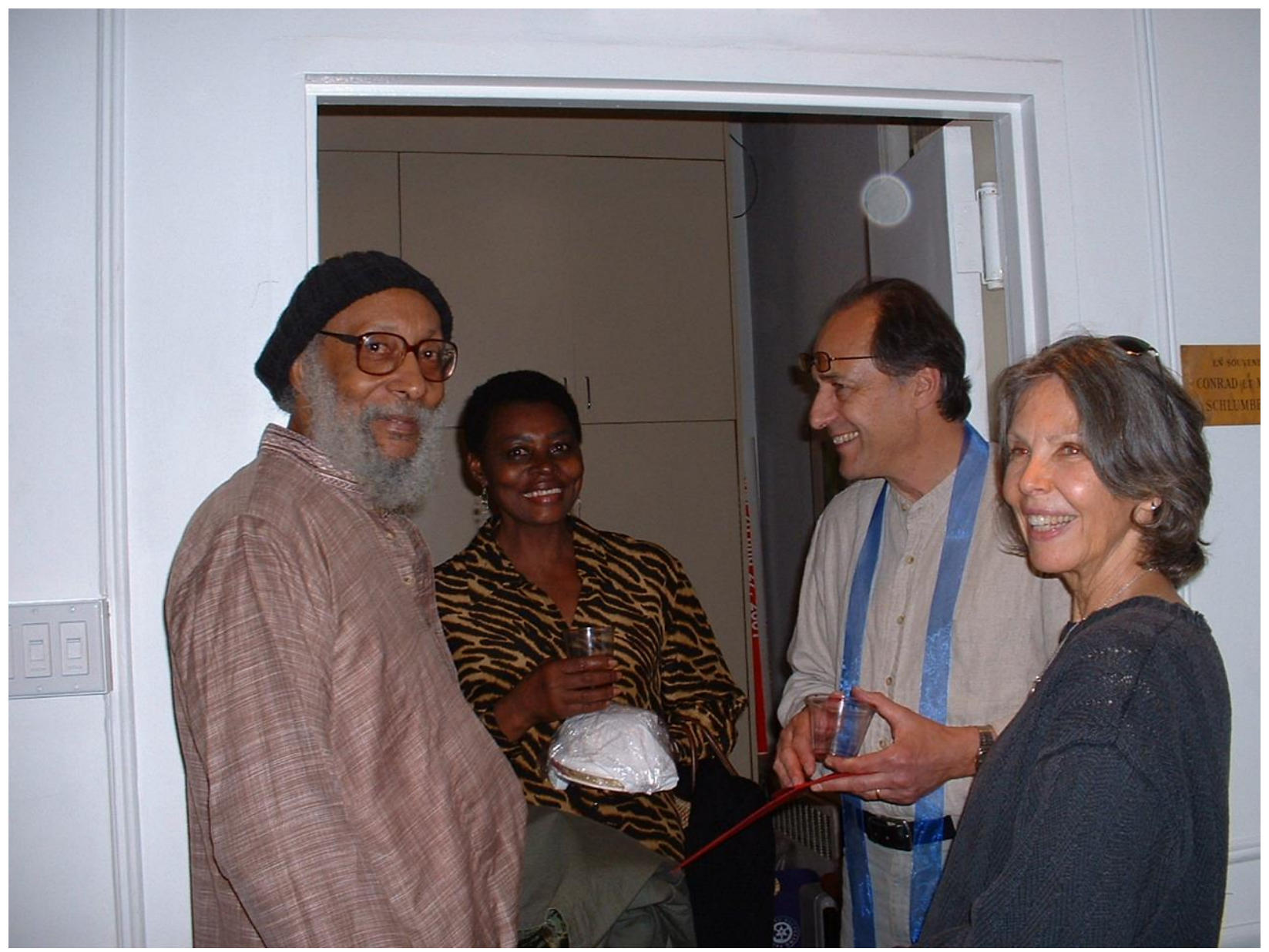

From Left to Right: Kamau Brathwaite, Beverley Brathwaite, Timothy Reiss, Patricia Penn Hilden 